\title{
Embryology of Onagraceae (Myrtales): characteristics, variation and relationships
}

\author{
Hiroshi Tobe and Peter H. Raven
}

\begin{abstract}
Tobe, $H^{1}$ and Raven, P.H. ${ }^{2}{ }^{1}$ Department of Natural Environmental Sciences, Faculty of Integrated Human Studies, Kyoto University, Kyoto 606, Japan; ${ }^{2}$ Missouri Botanical Garden, P.O. Box 299, St. Louis, Missouri 63166, U.S.A.) 1996. Embryology of Onagraceae (Myrtales): characteristics, variation and relationships. Telopea 6(4): 667-688. Here we report features of the embryology of 14 genera of Onagraceae, as a companion study to our earlier report on Ludwigia alone. We found that the 4-nucleate Oenothera type embryo sac that sharply distinguishes Onagraceae from all other Myrtales is common to all genera. Shared features of the nucellus and seed coat structure, however, indicate that Onagraceae more closely resemble Lythraceae than other Myrtalean families. Differences between onagraceous genera are found in 1) the mode of anther wall formation (the Basic or the Monocotyledonous type), 2) the number of cells in the ovule archesporium (one-celled or multi-celled), 3) the nature of early development of the inner integument (retarded or not retarded), and 4) the thickness of the parietal tissue in the nucellus (thin or thick). Based on comparisons in these and other embryological characteristics, we have concluded that: 1) Ludwigia (Jussiaeeae) differs sharply from the rest of the family in having a one-celled archesporium in its nucellus; 2) Hauya (Hauyeae) and eight of the genera of Onagreae (except Gayophytum) closely resemble one another but differ from the other genera of the family in their markedly thick parietal tissue in the nucellus; 3) Gayophytum, unlike other Onagreae, resembles Epilobium (now including Boisduvalia) in having retarded early development of its inner integument and in having thin parietal tissue; 4) Clarkia heterandra (formerly segregated as the monotypic genus Heterogaura) differs from other species of Clarkia and from other Onagreae (except Gayophytum) in its nucellar histology.
\end{abstract}

\section{Introduction}

Onagraceae are a well-defined plant family, comprising seven tribes, 16 genera and about 650 species (Raven 1979, 1988; Hoch et al. 1993). The family belongs to the order Myrtales (Dahlgren \& Thorne 1984; Johnson \& Briggs 1984; Chase et al. 1993), but is quite isolated, marked as monophyletic by at least five autapomorphies (for review, see Raven 1988). Leaf, wood and floral anatomy have been studied extensively; chromosome numbers are known for most taxa and chromosome morphology for all major groups; and breeding systems and pollinators, flavonoids and palynology have been investigated for much of the family (see Raven 1988; Hoch et al. 1993). Recent molecular analyses of relationships in the family, summarized in Conti, Fischbach \& Sytsma (1993), while not entirely consistent with one another, nevertheless have provided phylogenetic models within which to examine comparative data from other sources.

Regarding the embryology of the family, about 100 publications are available from a bibliography compiled by Davis (1966: for publications until 1965) and Nagendran \& Dinesh (1989: for articles published between 1965-1985). Most of the works published from the 19th century to the middle of the 20th century had described micro- and megasporogenesis and megagametogenesis (i.e., embryo sac formation) using light microscopy. In these works, the distinctive pattern of megasporo- and megagametogenesis named the 'Oenothera' type, which was reported by Geerts (1908) in Oenothera glazioviana ('O. lamarckiana') for the first time, was confirmed in 12 of the 16 genera. More recently, many studies have used fluorescence or transmission electron microscopy to investigate 
the megasporogenesis of Oenothera and Epilobium in relation to polarity and the competition between megaspores in a tetrad, or their megagametogenesis to form the 4-nucleate Oenothera type embryo sac. Until recently, relatively little attention has been paid to other embryological characters, and many of more than 50 characters that we discuss in this paper have remained unstudied, including such features as the development of anthers, ovules (the integuments and nucellus in particular) and seeds. We have presented analyses of certain embryological characters in the whole family, specifically, on the histogenesis of integuments (Tobe \& Raven 1985) and on the divided (or septate) sporogenous tissue of anthers (Tobe \& Raven 1986a). Subsequently, we examined some 40 embryological characters in 11 species of Ludwigia, representing seven of its 23 sections (Tobe \& Raven 1986b). As a result, except for the above characters of the anther and integuments, we now can summarize the present level of knowledge as follows: Ludwigia is thoroughly known; Oenothera, Clarkia (now including Heterogaura heterandra; Lewis \& Raven 1992), Chamerion and Epilobium (now including Boisduvalia; Hoch \& Raven 1992) are relatively well known; Circaea, Lopezia, Camissonia, Gayophytum and Stenosiphon are known to a limited degree; and Fuchsia, Gongylocarpus, Hauya, Xylonagra, Calylophus and Gaura are little known or unknown (for references to individual genera, see footnotes in Tables 2-4).

The purpose of this paper is to clarify embryological attributes of all genera of Onagraceae in order to provide a basis for comparison with other families and within the family, and, on the basis of additional embryological evidence, to discuss familial and generic relationships. For this purpose we have investigated one or more species of 14 onagraceous genera (Table 1). Subsequent to the specimen examination and data collection for this study, it has been demonstrated that Chamerion should be segregated from Epilobium (Baum, Sytsma \& Hoch 1994; Hoch, unpublished data). No collection of Chamerion was included in our specimens, however, there are several reports for it in the literature (Lebègue 1948b, among others). Because there is no evidence of embryological differences between these two groups in the available reports, we have not treated Chamerion separately in this report. Our previous study of Ludwigia (Tobe \& Raven 1986b) indicated that most embryological features (except for those of embryogenesis and seed coat anatomy) do not vary within a genus. This relationship allows us to use one or a few species as representative of the general embryological features of each genus in the absence of other information. We have also incorporated previously published information about embryology of Onagraceae, evaluating it and presenting it along with our own results.

\section{Materials and methods}

Thirty-three species representing 14 genera were investigated. All three major components of embryology - i.e., anthers, ovules and seeds - were examined in each species for which sufficient material was available (Table 1). Samples of flower buds and fruits in various stages of development were fixed in FAA ( 5 parts stock formalin; 5 parts glacial acetic acid; 90 parts $70 \%$ ethanol). Observations were made using serial microtome sections, except that the number of cells in a mature pollen grain was observed using whole pollen grains stained with $1 \%$ aceto-carmine (Tobe \& Raven 1984). Methods for preparing microtome sections are presented elsewhere (Tobe \& Raven 1986b).

We have made a sufficient number of observations to determine the type of embryogenesis in only a few genera, although some features of embryogenesis are reported for most of our samples. Likewise, we report here only limited information about seed coat structure, which nearly always varies within individual genera (e.g., Oenothera, see Tobe, Wagner \& Chin 1987; Ludwigia, see Tobe \& Raven 1986b; Tobe, Raven \& Peng 1988), because our focus in this paper is on generic relationships. 
Table 1. Species examined, collection information, and reproductive parts examined. Key: + , examined; (+), partially examined; - , not examined.

\section{Species}

Tribe Fuchsieae

Fuchsia jimenezii

Breedlove, Berry, \& Raven

F. paniculata Lindley

F. radicans Miers

Tribe Circaeeae

Circaea alpina L.

subsp. pacifica

(Asch. \& Magnus) Raven

C. cordata Royle

Tribe Lopezieae

Lopezia langmaniae Miranda

L. racemosa Cav.

subsp. racemosa

Tribe Hauyeae

Hauya elegans DC.

subsp. elegans

H. heydeana Donn.Sm.

Tribe Onagreae

Gongylocarpus fruticulosus

(Benth.) Raven \& Breedlove

G. rubricaulis

Schldl. \& Cham.

Gayophytum humile A. Juss.

G. ramosissimum Torrey \& A. Gray

Xylonagra arborea (Kellogg) Donn.Sm. \& Rose

Camissonia californica (Nutt. ex Torrey \& A. Gray) Raven

C. ovata (Nutt. ex Torrey \& A. Gray) Raven

Calylophus hartwegii (Benth.) Raven subsp. fendleri (A. Gray) Towner \& Raven

C. lavandulifolius (Torrey \& A. Gray) Raven

C. serrulatus (Nutt.) Raven

Gaura boquillensis Raven \& Gregory

G. longiflora Spach

G. mutabilis Cav Oenothera flava (A. Nelson) Garrett subsp. flava

O. fruticosa L. subsp. fruticosa

\section{Collection}

Costa Rica, Monteverde, Haber,

Baker \& Baker 434 (MO)

Mexico, Chiapas, Breedlove 42742 (MO)

Brazil, São Paulo, Campas de Jordao,

Ramamoorthy 676 (MO)

Cult., Univ. British Columbia Bot. Gard. (UBC) Cult., Missouri Bot. Gard. \#762431; plants from USSR, Vladivostok, Raven in 1975 (MO)

Mexico, Chiapas, Breedlove 32300 (CAS)

Mexico, Chiapas, Breedlove 7030 (CAS)

Mexico, Chiapas, Breedlove 42631 (MO)

Mexico, Chiapas, Breedlove 15669 (MO)

Mexico, Baja California, Magdalena Is., Verity 037 (MO)

Mexico, Chiapas, Breedlove 41880 (MO) U.S.A., Oregon, Jefferson Co., Chambers 4834 (OSC)

U.S.A., Oregon, Deschutes Co., Chambers 4817 (OSC)

Mexico, Baja California, Verity, Nakai, \& Angel in 1979 (MO)

Cult., UCLA Bot. Gard., Verity s.n., no voucher U.S.A., California, Marin Co., Raven \& Raven 26148 (MO)

U.S.A., Texas, Jeff Davis Co., Powell 3621 (MO)

S. A., Nevada, Lincoln Co., Tiehm \& Williams $6572(\mathrm{MO})$.

U.S.A., Kansas, Pecos Co., Brooks 15533

(KANU)

U.S.A., Texas, Brewster Co., Powell \&

Powell 3608 (MO)

U.S.A., Missouri, Jefferson Co., Wagner, Mill, \& Tobe $4522(\mathrm{MO})$

Mexico, Mexico, Rzedowski 34992 (ENCB)

Mexico, Durango, Wagner \& Solomon 4321

(MO)

Cult., Missouri Bot. Gard. \#M1908; plants

from U.S.A., North Carolina, Pender Co.,

Boufford et al. 21575 (CM) (t)

(+)

$+\quad+\quad(+)$

(+)

Parts examined Anthers Ovules Seeds

$\begin{array}{ccc}+ & + & - \\ + & + & - \\ + & + & (+)\end{array}$

$\begin{array}{lll}+ & + & + \\ + & + & +\end{array}$

$+$

(+)

$+$

$(+)$

$(+)$

$+\quad+$


Table 1 (continued).

Species

O. villosa Thunb. subsp. villosa

Stenosiphon linifolius (Nutt.) Heynhold

Clarkia dudleyana (Abrams)

J. F. Macbr.

C. heterandra (Torrey)

H. Lewis \& Raven

[Syn: Heterogaura heterandra (Torrey) Cav.]

C. tenella (Cav.) Lewis \&

Lewis subsp. tenella

Tribe Epilobieae

Epilobium canum (Greene)

Raven subsp. canum

E. ciliatum Raf. subsp. watsonii (Barbey) Hoch

\& Raven

E. concinnum (D. Don)

Hoch \& Raven

[Syn: Boisduvalia subulata

(Ruiz \& Pavón) Raimann]

E. pygmaeum (Speg.)

Hoch \& Raven

[Syn: Boisduvalia glabella

(Nutt.) Walp.]

\section{Collection}

U.S.A., Missouri, St. Louis Co., Wagner, Mill, \& Tobe 4519 (MO)

U.S.A., Oklahoma, McClain Co., Sullivan 1038 (OKL)

U.S.A., California, Gottlieb 129

U.S.A., California, Tuolumne Co., Gottlieb

in 1977 (MO)

Chile, Malleco, Curacao, Marticorena \& Ovezada 1669 (MO)

Cult., Univ. Calif. Bot. Gard. (Berkeley), UCBG 58.996 (UC)

U.S.A., California, Marin Co., Sharp in 1967 (MO)

Chile, Nuble, Cheese \& Watson 4405 (K)

U.S.A., California, Yolo Co., Crampton 9212

(MO)
Parts examined Anthers Ovules Seeds

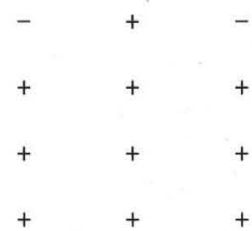

$+$

$\begin{array}{llll}+ & + & + \\ + & & + & +\end{array}$

$(+)$

\section{Results}

Most embryological characters examined were constant within the entire family (Tables 2-4). In these tables, features reported earlier are indicated with an asterisk $\left.{ }^{*}\right)$; all other features are reported here for the first time. All features mentioned in the following discussion are common to the entire family, as far as known, unless differences between genera and species are mentioned specifically.

Anthers and microspores (Table 2): In general, the anther wall varies from five to six cell-layers thick, but it is often three or four cell-layers thick in Gayophytum and four cell-layers thick in Clarkia heterandra. The anther wall is basically composed of an epidermis, an endothecium, two or three middle layers and a tapetum. In most genera the middle layers share their histogenetic origin with both the endothecial and the tapetal cells (i.e., Basic type; Fig. 1), although both or either of the middle layers may be lacking in Gayophytum. However, in Hauya, Calylophus, Gaura and Clarkia, the middle layers have a common histogenetic origin with the tapetal cell (i.e., Monocotyledonous type; Fig. 2). In Calylophus and Gaura, the Basic type also occasionally occurs, but it is not the predominant condition.

As the anther develops, the middle layers are completely crushed. The epidermis is basically persistent until the time of anther dehiscence, although it may collapse locally. The endothecium always develops fibrous thickenings. The tapetum is glandular and its cells become two-nucleate. We did not see any tapetal cells with more than three nuclei in the species we examined, although Geerts (1909) has reported two- to four-nucleate tapetal cells in Oenothera glazioviana ('O. lamarckiana').

Meiosis in the microspore mother cells was accompanied by simultaneous cytokinesis in the material we examined. The arrangement of microspores in a tetrad is mostly 
tetrahedral. Decussate or isobilateral arrangements also occur, but at low frequencies. Pollen grains are two-celled when shed.

Ovular orientation and integuments (Table 3): The ovule is anatropous and bitegmic, and the micropyle is formed by both integuments. For Stenosiphon, Johansen (1930b) reported that 'the inner integument is prolonged into a beak-like process,' and presented drawings of ovules showing the micropyle formed by the inner integument alone (1930b: 319, Figs 6, 7 [sterile ovule]). However, we have confirmed that the micropyle of Stenosiphon is also formed by both integuments. The micropyle appears to be formed largely by the endostome of a highly prolonged inner integument, but the outer integument is also prolonged and its tip exceeds that of the inner integument. A more or less prolonged inner (and outer) integument of this kind was observed in other genera of tribe Onagreae (e.g., Calylophus) and is not restricted to Stenosiphon as a characteristic feature. At any rate, its appearance accounts for Johansen's misinterpretation.

Early in ontogeny both the inner and the outer integument arise almost simultaneously, or the inner integument arises a little earlier than the outer one, from an ovular primordium (see Tobe \& Raven 1985: 452, Figs 1A, B; 459, Fig. 4A). In subsequent stages of development in most genera (generally up to the megaspore mother cell stage), the two integuments grow together, so that the tip of the inner integument exceeds that of the outer integument or reaches the top of nucellus earlier than the latter (Fig. 3). However, in the species examined of Epilobium (Figs 4,5) and Gayophytum (Fig. 6) the development of the inner integument is extremely retarded. For instance, at the megaspore mother cell stage, the inner integument is much shorter than the outer one, whereas the tip of the outer integument reaches near the top of the nucellus. In a few ovules of Oenothera flava, the inner integument was somewhat shorter than the outer one, but most samples of
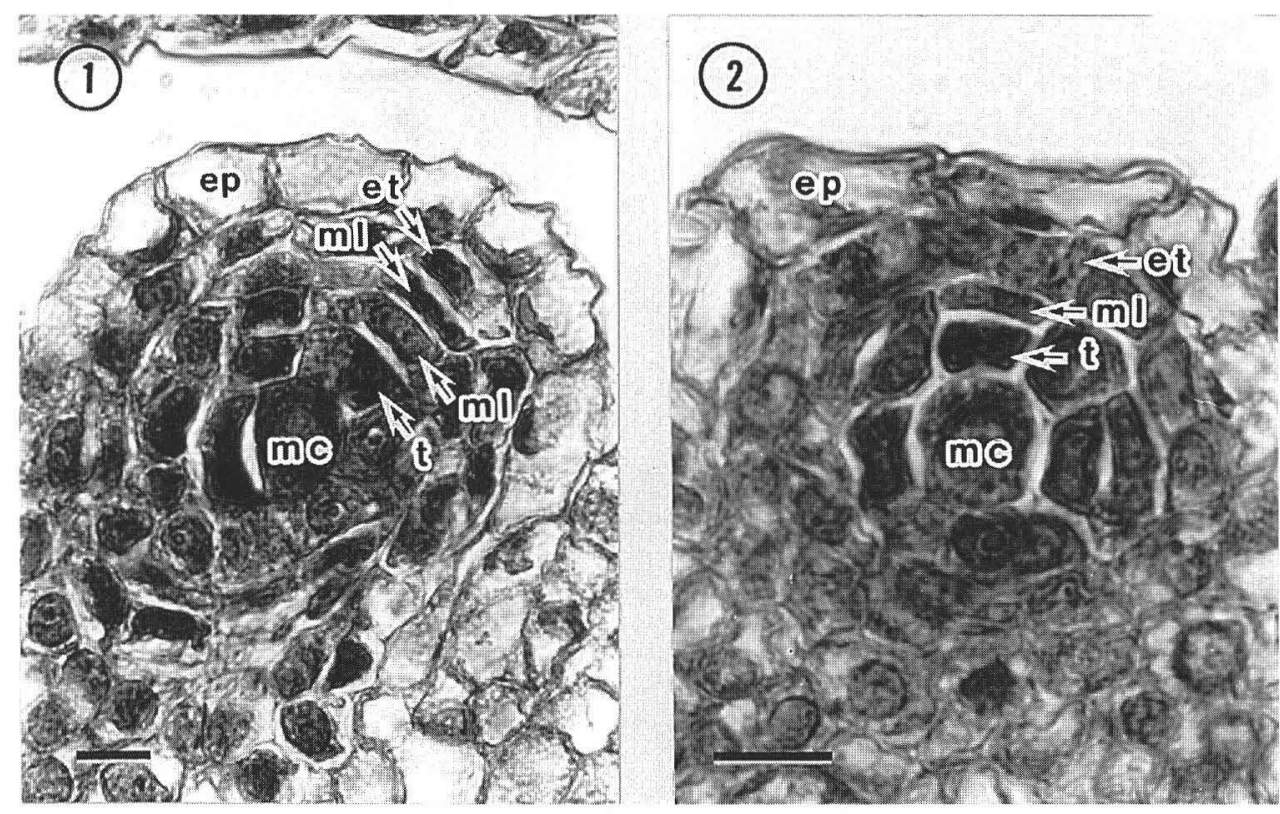

Figs 1 and 2. Transverse sections of young anthers showing two different types of wall formation. 1. Basic type (photo from Oenothera fruticosa). 2. Monocotyledonous type (photo from Clarkia dudleyana). See text for explanation. Abbreviations: et, endothecium; ep, epidermis; mc, microspore mother cell; ml, middle layer; $t$, tapetum. Scales equal $10 \mu \mathrm{m}$. 
this species and all those of other species of Oenothera examined do not have shorter inner integuments. An obturator is absent.

Megagametophyte and nucellus (Table 3): The archesporium in Onagraceae is multicelled, comprising three to five cells. Archesporial cells are usually distinguished from somatic cells by their larger size, denser cytoplasm and more prominent nucleus (Maheshwari 1950). However, it was very difficult to determine the number of archesporial cells, because the difference is not conspicuous between the archesporial and the somatic cells. We often confirmed the presence of a multi-celled archesporium
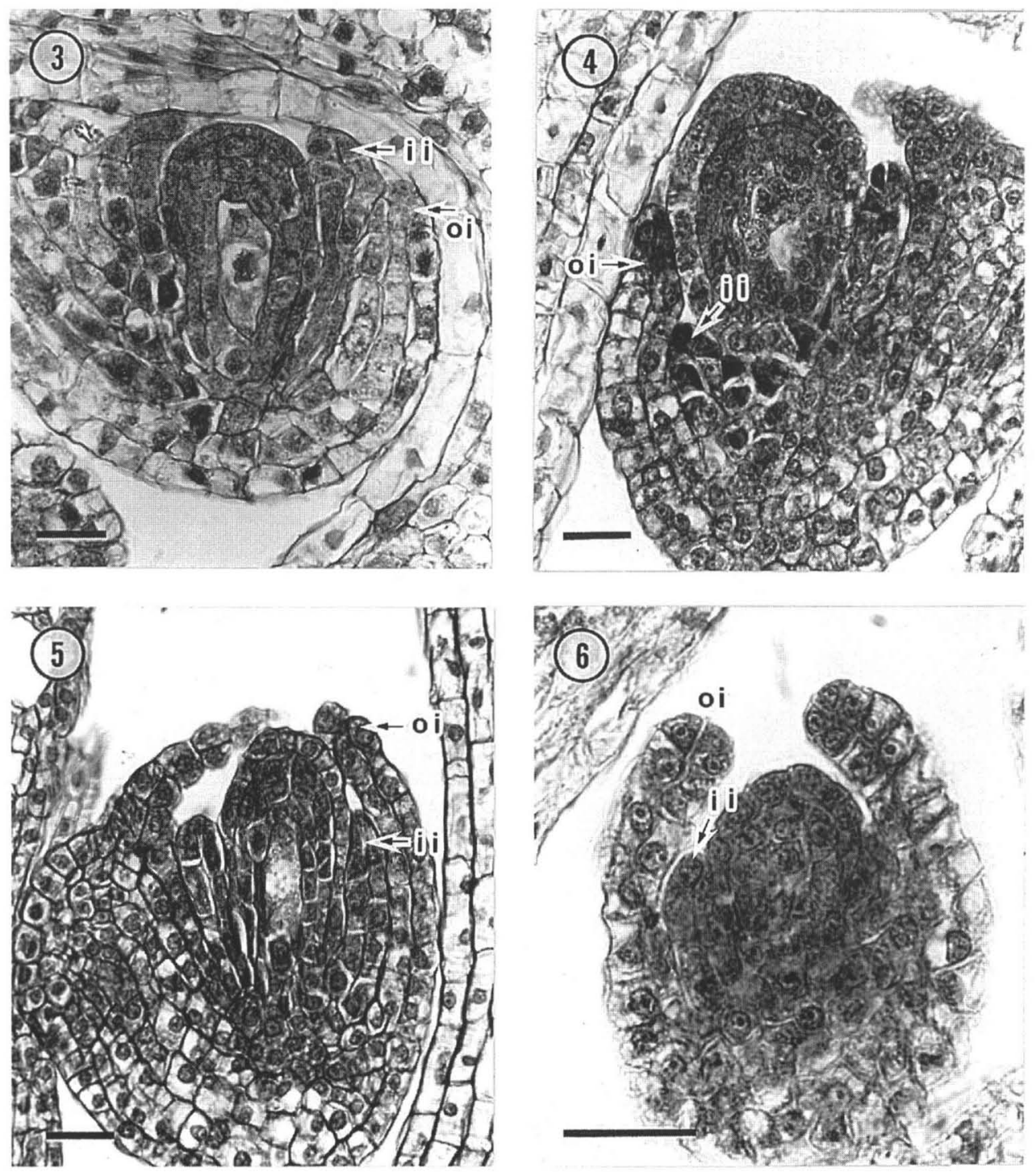

Figs 3-6. Longitudinal sections of young ovules showing early development of integuments. 3. Lopezia racemosa. 4. Epilobium canum subsp. canum. 5. Epilobium concinnum (Boisduvalia subulata). 6. Gayophytum ramosissimum. In contrast to that of most genera (for example, as in Fig. 3), the inner integument (ii) of Epilobium and Gayophytum (Figs 4-6) is extremely retarded in early development and is much shorter than the outer integument (oi). All scales equal $20 \mu \mathrm{m}$. 
by looking at periclinal divisions of several hypodermal archesporial cells that give rise to the primary parietal and the sporogenous cells (Figs 7, 8: Fuchsia radicans).

Most earlier authors have not specified the number of archesporial cells, but have implied that the archesporium is one-celled (see Davis 1966; Seshavataram 1970). Nevertheless, the occurrence of a multi-celled archesporium has occasionally been reported in various species and genera of Onagraceae, although without reference to

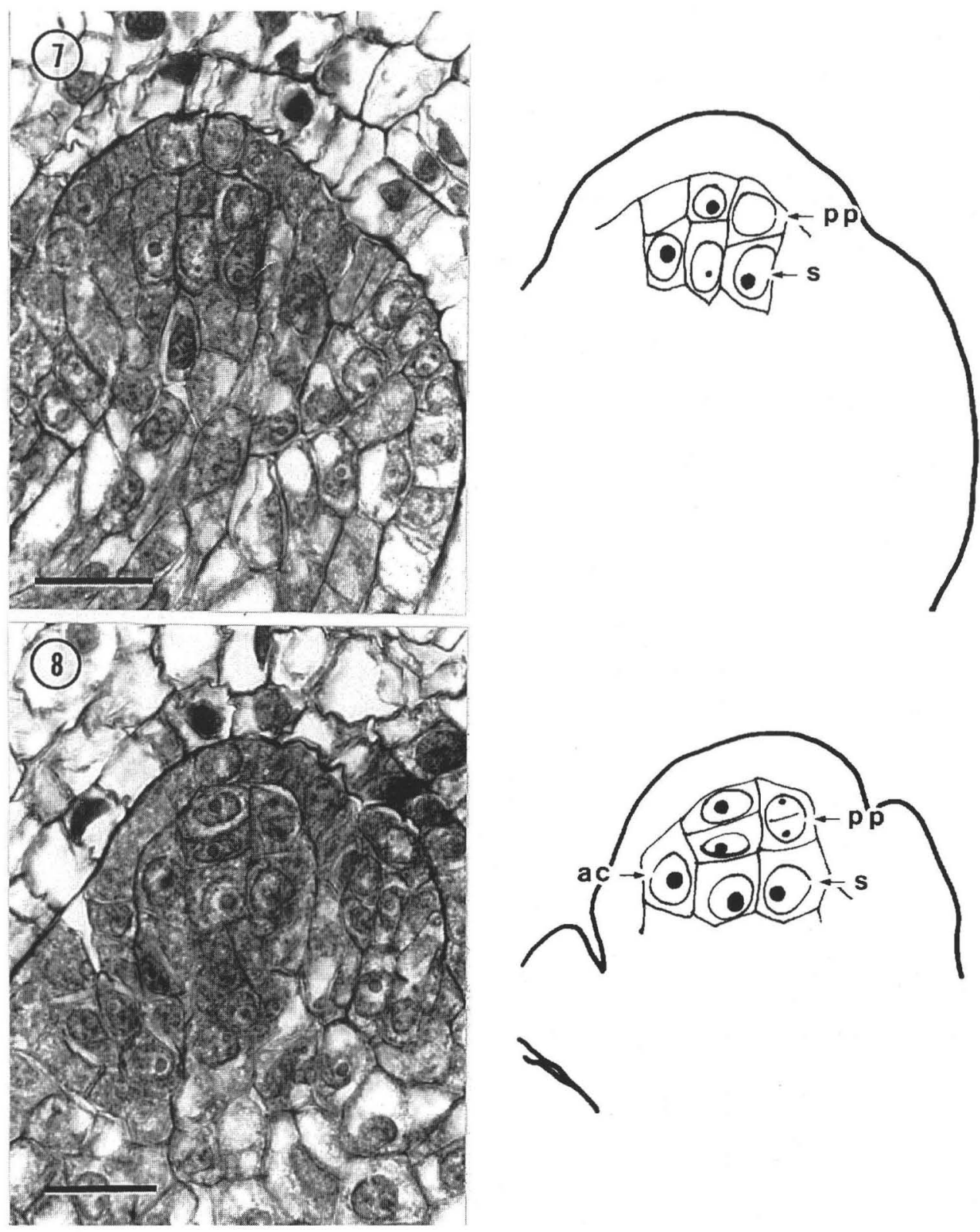

Figs 7 and 8. Longitudinal sections of two young ovules of Fuchsia radicans showing a multi-celled archesporium. Plural archesporial cells (ac) are differentiated, and most of them divide periclinally to give rise to the primary parietal cell (pp) and the sporogenous cell (s). Scales equal $20 \mu \mathrm{m}$. 
its relative frequency, for example, in Epilobium (Michaelis 1925), Lopezia (Täckholm 1914) and Oenothera (Hulbary \& Rao 1959; O’Neal 1923; Subramanyam \& Govindu 1948). In his study of Oenothera tetraptera ('Hartmannia tetraptera'), Johansen (1929: 289) corrected his early notes on the archesporium, from 'probably several archesporial cells [exist]' to 'a single archesporial initial [exists],' stating that 'cells adjoining the archesporial initial may often simulate the functional appearance of the latter.' However, all samples of Onagraceae we examined had plural archesporial cells in conformity with a few earlier reports of the occasional occurrence of plural archesporial cells (e.g., Hulbary \& Rao 1959; Michaelis 1925; O'Neal 1923; Subramanyam \& Govindu 1948), as well as of plural megaspores (derived from different archesporial cells) and embryo sacs (e.g., Langendorf 1930; Renner 1914; Täckholm 1915). These earlier reports also seem to suggest that the multi-celled archesporium is prevalent. We cannot confirm the existence of a one-celled archesporium in any Onagraceae.

Usually a sporogenous cell derived from one of the plural archesporial cells increases its volume and becomes a megaspore mother cell. The megaspore mother cell undergoes meiosis, forming nearly always a linear tetrad of megaspores (Figs 9-12) and very rarely an oblique linear tetrad. A triad of megaspores may also occasionally occur, resulting from the suppression of homotypic division in the lower cell of the dyad (for the frequencies of triads in certain genera, see Rodkiewicz \& Sniezko
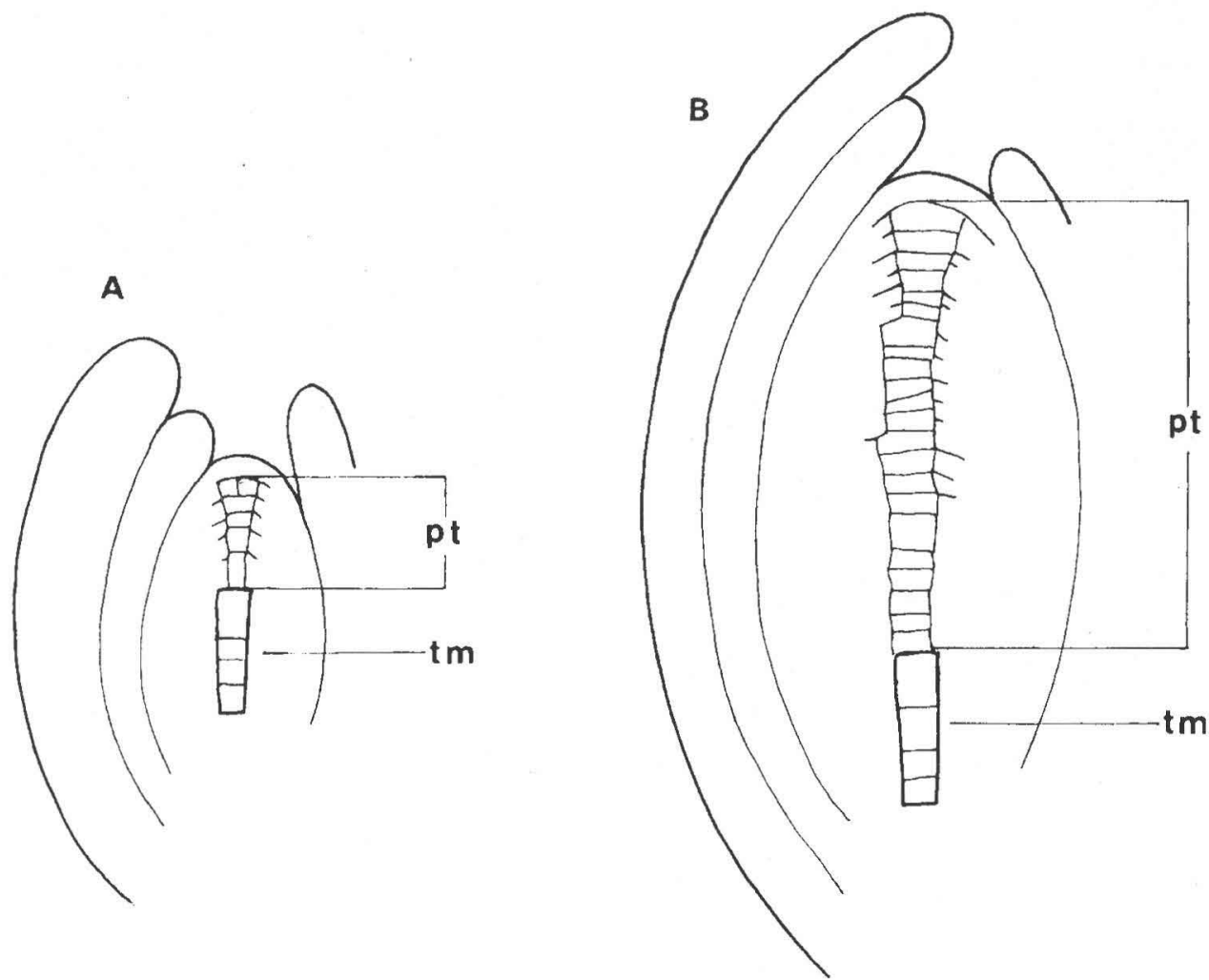

Fig. 9. Diagrams illustrating two contrasting ovules with respect to the thickness of parietal tissue (pt) lying above a tetrad of megaspores ( $\mathrm{tm}$ ). a. Ovule with a thin parietal tissue (5 cells thick). b. Ovule with a thick parietal tissue (22 cells thick). 

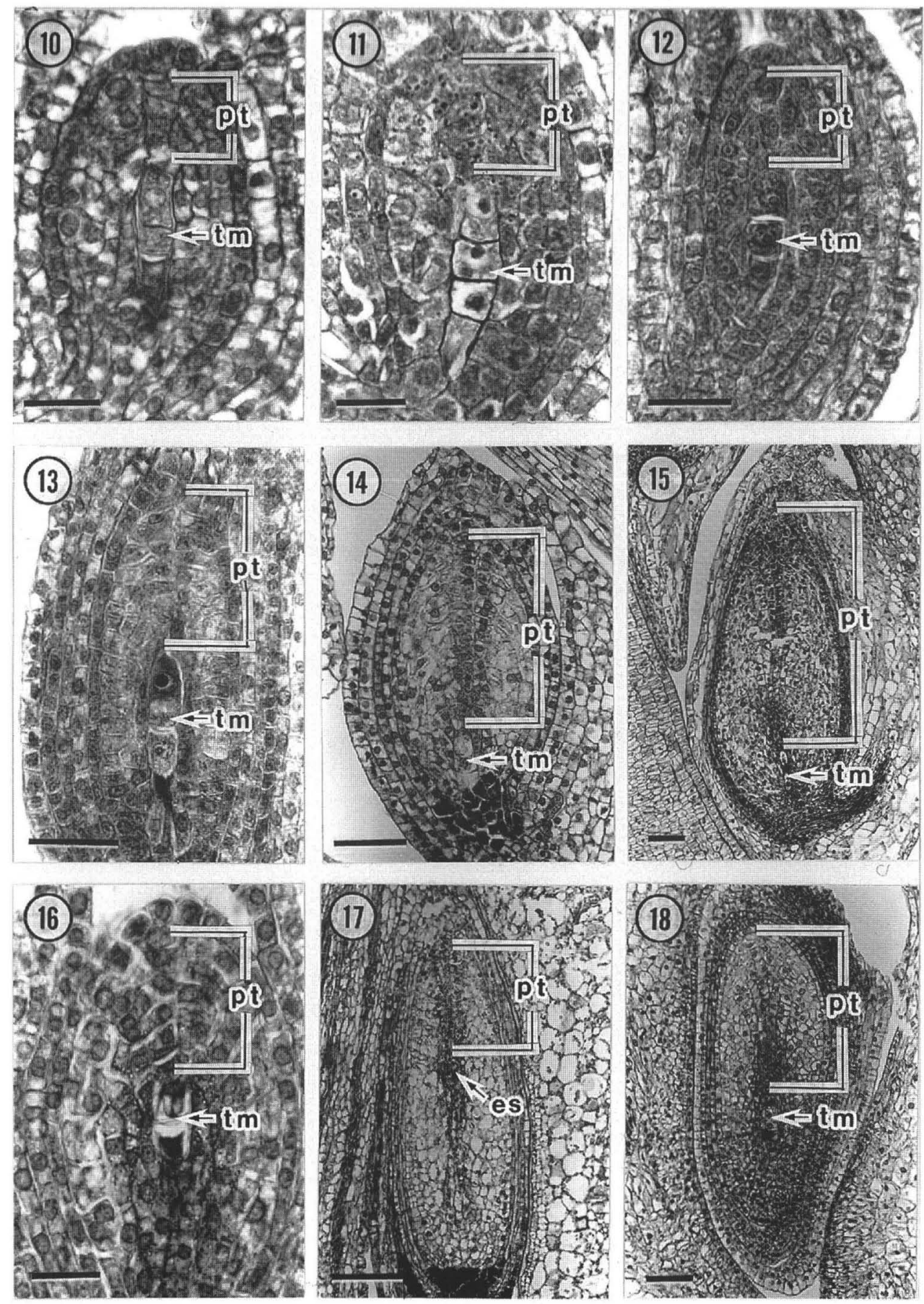

Figs 10-18. Longitudinal sections of ovules of some genera at the megaspore tetrad stage (Figs 10-16 and 18) and at the 2-nucleate embryo sac (es) stage (17), showing the thickness of parietal tissue (pt) and the position of a tetrad of megaspores (tm). 10. Fuchsia jimenezii. 11. Lopezia racemosa. 12. Epilobium ciliatum subsp. watsonii. 13. Gayophytum ramosissimum. 14. Clarkia tenella. 15. Hauya elegans. 16 and 17. Clarkia heterandra ('Heterogaura') 18. Gongylocarpus fruticulosus. See text for explanation. Scales equal $20 \mu \mathrm{m}, 20 \mu \mathrm{m}, 20 \mu \mathrm{m}, 20 \mu \mathrm{m}, 50 \mu \mathrm{m}, 100 \mu \mathrm{m}, 100 \mu \mathrm{m}, 20 \mu \mathrm{m}$ and $50 \mu \mathrm{m}$, respectively. 
1978). A micropylar megaspore in the tetrad is functional and enlarged (Fig. 13), while the three remaining megaspores degenerate. A chalazal megaspore, instead of the micropylar one, or both the micropylar and chalazal megaspores may rarely appear to be functional, but we have never observed the chalazal megaspore to develop into an organized embryo sac. The nucleus of the functional micropylar megaspore always is located on the micropylar side of the cell and, following its mitotic divisions, develops into a two- (Fig. 19) and a four-nucleate (or -celled) Oenothera type embryo sac (Fig. 20). An organized embryo sac has one egg cell, two synergids and one polar nucleus.

Some genera of Onagraceae differ markedly in the thickness of their nucellar tissue, particularly in the parietal tissue derived from archesporial cells (for two contrasting ovules, see Figs 9a, b). The primary parietal cell (see pp in Figs 7, 8) derived from the archesporial cell divides periclinally, and the two daughter cells continue to divide periclinally. Consequently, above the linear tetrad of megaspores lies a relatively thin layer of parietal tissue, about five to eight cells thick (Fig. 9a), as found in Fuchsia (Fig. 10), Circaea, Lopezia (Fig. 11), Epilobium (Fig. 12) and Gayophytum (Fig. 13), or a relatively thick layer, about ten to 20 cells thick (Fig. 9b), as found in Clarkia (Fig. 14), Hauya (Fig. 15), Gongylocarpus, Xylonagra, Camissonia, Calylophus, Gaura, Oenothera and Stenosiphon. In most genera the tetrad of megaspores is deeply buried in the nucellus and, except in Clarkia heterandra ('Heterogaura') and Gongylocarpus, is positioned at or a little above the bottom of the nucellus. Compared to other species of Clarkia, C. heterandra is unusual in that the divisions of the parietal cells are retarded and that a tetrad of megaspores is positioned in the middle of the nucellus (Fig. 16). At this stage, C. heterandra has a thin layer (about five to eight cells thick) of parietal tissue above and a somewhat thicker nucellar tissue below the megaspores (Fig. 16). In later stages of development, the cells of both tissues above and below divide rapidly, increasing their respective thickness, so that the embryo sac comes to be positioned in the center of the nucellus. At the two-nucleate embryo sac stage, the parietal tissue is up to 16 to 20 cells thick (Fig. 17). Gongylocarpus is similar to most other genera of the tribe Onagreae in having thick parietal tissue ( 18 to 20 cells thick) above the tetrad of megaspores, but less nucellar tissue than the other genera below the tetrad, so that the tetrad is positioned between the bottom and the center of the nucellus (Fig. 18).

A nucellar cap derived from the nucellar dermal cell by its periclinal division is two or three cells thick if present, but is relatively insignificant and poorly defined. For these reasons, we do not consider it to be a useful feature for making comparisons between genera.

Starch grains, whose functional aspects have sometimes been discussed in relation to the polarity of megaspores in a tetrad (e.g., Rodkiewicz \& Bednara 1974; Rodkiewicz \& Sniezko 1978; Sniezko \& Harte 1984a), are abundant in the nucellar cells, megaspores and embryo sac before fertilization, particularly on the micropylar side (Fig. 20). They become less conspicuous in the post-fertilization stages, however. Ishikawa (1918: 311) gives a comparison among some genera, noting that starch grains in the nucellus are 'many' in species of Oenothera, Gaura and Circaea, 'very few' in Chamerion angustifolium ('Epilobium') and 'none' in Clarkia ('Godetia sp.') and Fuchsia macrostemma. However, we have confirmed the presence of starch grains in the nucellus and the embryo sac in all species examined of all genera, including Epilobium, Clarkia and Fuchsia.

A hypostase, which is distinguished by accumulation of densely staining tannin-like substances in its cells and the thickening of those cell walls, is always formed although its differentiating stage is different from species to species. According to Johansen (1928), Oenothera, Gaura, Clarkia and Circaea possess a definite hypostase, whereas 

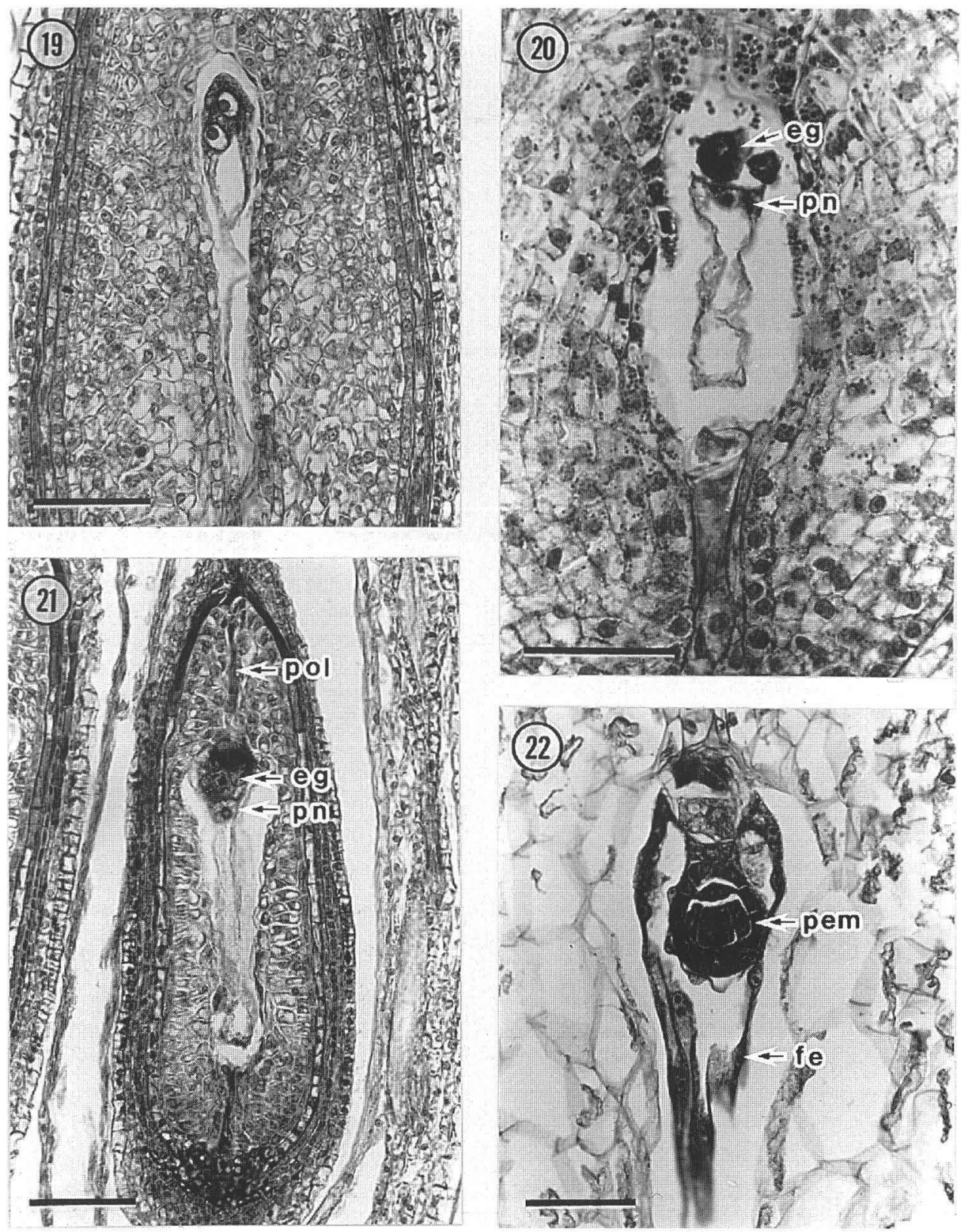

Figs 19-22. Longitudinal sections of ovules and seeds in various stages of development, showing general embryological features in older embryo sacs and nucelli. 19. Ovule with two-nucleate embryo sac (photo from Gaura mutabilis). Note two nuclei positioned on micropylar side. 20. Ovule with organized embryo sac composed of an egg apparatus (eg) and a single polar nucleus (pn); arrowheads indicate scattered starch grains in nucellus (photo from Fuchsia radicans). 21. Ovule with embryo sac just fertilized showing porogamy (photo from Gayophytum ramosissimum). See pollen tube (pol) penetrating into the nucellus on micropylar side. 22 . Seed with embryo sac containing free endosperm nucleus (fe) and a globular proembryo (pem) (photo from Clarkia heterandra). All scales equal $50 \mu \mathrm{m}$. 
the majority of species of Epilobium and Fuchsia are characterized by its absence. However, we have confirmed the presence of a hypostase in all species examined of Epilobium and Fuchsia, as well as in the other genera for which information on the hypostase has not been available earlier. It appears, therefore, to be common to all species of Onagraceae.

Fertilization, endosperm and embryo (Table 4): Fertilization is porogamous (Fig. 21). Johansen (1934) reports irregularities with respect to the path of pollen tube in ovules of Circaea alpina subsp. pacifica, but we were not able to confirm his observations in the material of this taxon that we examined. Endosperm formation is of the Nuclear type (Fig. 22). The endosperm is scanty throughout the process of seed development. Even in a nearly mature seed, a limited amount of cellularized endosperm is present on the periphery of the embryo sac and particularly on the chalazal side (Fig. 28). The mature seed completely lacks endosperm (e.g., in Fuchsia, Fig. 23, and Gongylocarpus, Fig. 26).

Earlier, the Onagrad type of embryogeny has been reported in species of Circaea (Souèges 1946), Oenothera (Souèges 1920), Chamerion (Lebègue 1948b) and Epilobium (Lebègue 1948a). We observed the Onagrad type in Gayophytum humile, Camissonia ovata and Clarkia heterandra. The embryo in a mature seed is straight and dicotyledonous with a short suspensor (Fig. 26).

Seed appendage and seed coat (Table 4): Except in Hauya, Xylonagra, Chamerion and Epilobium, the seeds of Onagraceae have no conspicuous appendages. Both Hauya and Xylonagra have a wing on the chalazal side. The wing is flat along the axis of raphe to antiraphe. All species of Chamerion and all but a few species of Epilobium (especially species of the former Boisduvalia) have a coma on the chalazal end of the seed that is composed of a tuft of unicellular trichomes.

The mature seed coat basically comprises the exotesta, endotesta, exotegmen and endotegmen. In addition, a mesotesta is present in Fuchsia (Figs 23, 24), Circaea (Fig. 25), Lopezia, Oenothera (some species only) and Stenosiphon (Tobe, Wagner \& Chin 1987), whereas Gongylocarpus (Figs 26, 27), Xylonagra (Figs 28, 29) and all other genera lack a mesotesta. As mentioned previously, we did not examine the variation of seed coat structure within particular genera, which is often extensive, for the purposes of this paper. The following are common features characteristic of the whole family. The endotesta, which may be relatively less conspicuous in some species of various genera than usual for the family, is crystaliferous, and its cells are variously thick-walled; the exotegmen is composed of longitudinally elongate fibrous (or tracheoidal) cells; the endotegmen comprises longitudinally elongate, tanniniferous cells. Carlquist \& Raven (1966) described the seed coat histology of Gongylocarpus rubricaulis as entirely different from that of G. fruticulosus, but we found them to be similar (G. rubricaulis, Fig. 27); both species share a crystaliferous endotesta and a fibrous exotegmen.

\section{Discussion}

In 1983, on the basis of the limited information then available, we discussed the relationships of Onagraceae with the other families of the order Myrtales. We concluded that 'none of the embryological attributes of Onagraceae suggests a particular relationship either to Lythraceae or to any other family' (Tobe \& Raven 1983: 86-87). As a result of our subsequent studies, (see Tables 2-4; Tobe \& Raven 1986b), however, we have confirmed that most embryological features such as the Oenothera type embryo sac, are common to the entire family Onagraceae. With respect to the relationships of the family, we offer the following observations. First, the Oenothera type embryo sac distinguishes Onagraceae from all other myrtalean families. Second, the presence of the multi-celled ovule archesporium (except in Ludwigia), as well as the presence of starch grains in the 
nucellus, suggest close resemblance between Onagraceae and Lythraceae (for the presence of multi-celled ovule archesporium and starch grains in Lythraceae, see Hubert, 1896; Joshi \& Venkateswarlu 1935a, b, 1936; Venkateswarlu 1937). Third, the combination of a crystaliferous endotesta and a fibrous exotegmen indicates relationships of Onagraceae with Lythraceae and Sonneratiaceae, but not with other families including Myrtaceae and Melastomataceae. Thus we now would conclude that embryological features do support the traditional view that Onagraceae are directly related to Lythraceae. We shall
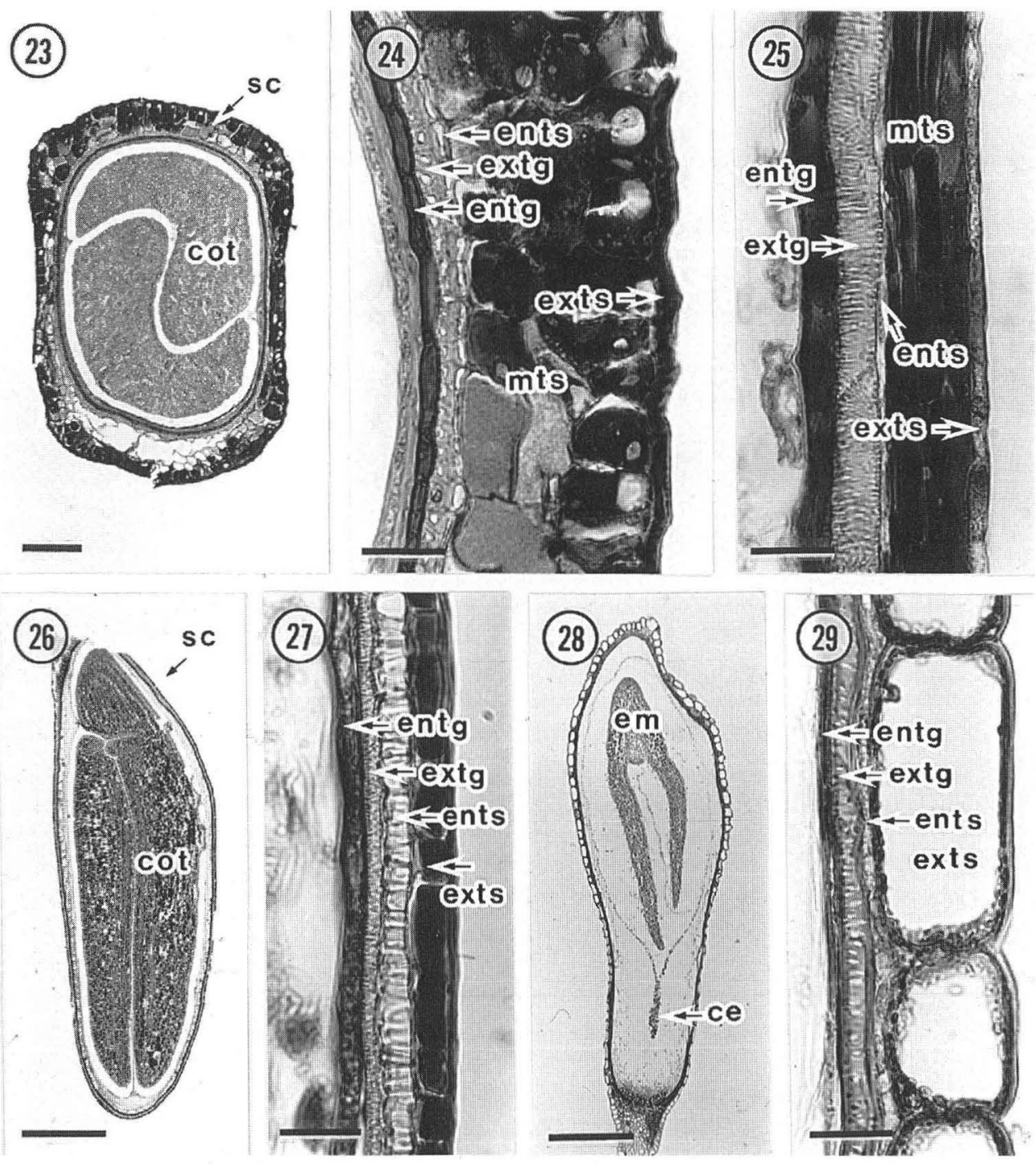

Figs 23-29. Transverse (23 and 24) and longitudinal sections (25-29) of seeds showing seed and seed coat structure in various genera. 23-27. Mature seeds. 28-29. Immature seeds. 23-24. Seed and seed coat of Fuchsia jimenezii. 25. Seed coat of Circaea cordata. 26-27. Seed and seed coat of Gongylocarpus rubricaulis. 28-29. Seed and seed coat of Xylonagra arborea. Note that the seed coats of Fuchsia and Circaea are thick and have mesotesta (mts), whereas those of Gongylocarpus and Xylonagra are thin and lack mesotesta. Additional abbreviations: ce, cellular endosperm; cot, cotyledon; em, embryo; entg, endotegmen; ents, endotesta; extg, exotegmen; exts, exotegmen; sc, seed coat. 
continue to consider the relationships of Onagraceae as additional information on the embryology of other families of Myrtales becomes available.

Relationships within Onagraceae: A comparison among the genera of Onagraceae indicates that the following four embryological features differ significantly within the family. (1) Anther wall development is predominantly either the Basic or the Monocotyledonous type; (2) the ovule archesporium is one- or multi-celled; (3) the inner integument is retarded in development or not; and (4) the parietal tissue lying above the tetrad of megaspores is either thin or thick. The distribution of features of these four characters within Onagraceae is presented in Table 5, along with that of features of integumentary histogenesis (Tobe \& Raven 1985) and of divided microsporangium (Tobe \& Raven 1986a), features that we found earlier to differ within the family.

Ludwigia is the only genus that characteristically has a one-celled ovule archesporium, in contrast to the multi-celled archesporium in all other genera. Ludwigia now appears unambiguously to be a sister group to the remainder of the family, particularly on the basis of evidence from floral morphology and anatomy (Eyde 1981; Hoch et al. 1993) and from molecular analyses of both ribosomal DNA (Bult \& Zimmer 1993) and chloroplast $r b c \mathrm{~L}$ data (Conti, Fischbach \& Sytsma 1993). For example, Ludwigia has floral nectaries on the gynoecium, instead of at the gynoecium and floral tube junction as in all other genera, and both central and transseptal bundles for ovule supply, instead of only transseptal bundles as in all other genera (Eyde 1981). The difference in the number of archesporial cells in an ovule supports the hypothesis that Ludwigia does indeed represent an evolutionary branch separate from the rest of the family.

Hauya (Hauyeae) and all genera of the tribe Onagreae except Gayophytum agree with one another in having markedly thick parietal tissue in the ovule. Hauya further agrees with Calylophus, Gaura, and Clarkia of Onagreae in having the Monocotyledonous type anther wall formation, instead of the Basic type common to all other genera. Coincidences between Hauya and members of Onagreae have already been indicated by other embryological evidence. For instance, Hauya shares with Calylophus and Gaura a distinctive histology of the outer integument (Tobe \& Raven 1985), and also shares with Calylophus, Gaura and Clarkia the apparent apomorphy of microsporogenous tissue divided by septa composed of parenchyma and tapetum into many small packets (Tobe \& Raven 1986a). This evidence, thus, suggests a close relationship of Hauya with tribe Onagreae, particularly with Calylophus and Gaura, and probably also with Clarkia. However, several molecular analyses using both nuclear (Crisci et al. 1990; Bult \& Zimmer 1993) and chloroplast DNA (Sytsma, Smith \& Hoch 1991; Conti, Fischbach \& Sytsma 1993), contradict this placement of Hauya near Onagreae, instead supporting a close relationship of Hauya to Fuchsia and Circaea. Ongoing molecular analyses that include all relevant taxa and 'total-evidence' analysis of the studies already available may resolve this controversy, and provide a robust hypothesis within which to interpret the evolution of these embryological characters. The chalazal seed wing shared by both Hauya and Xylonagra seems to represent a parallel (homoplasious) evolution, since no other evidence supports a close relationship between them.

In Gayophytum, unlike other members of the tribe Onagreae, but like Epilobium (tribe Epilobieae), the early development of the inner integument is retarded. In addition, Gayophytum resembles Epilobium, rather than other Onagreae, in having thin parietal tissue in the ovule. This rather surprising suggested relationship appears to be supported by sequence data from analysis of the internal transcribed spacer region (ITS) of the nuclear ribosomal gene (Baum \& Sytsma, unpublished data). This suggests that Onagreae may not be monophyletic because Epilobieae appears to be nested within it; the two tribes together, however, appear to form a monophyletic group. 
Some comments seem in order regarding the embryological features of Clarkia heterandra, which until recently has been segregated as the genus Heterogaura, but is now unambiguously assigned to Clarkia as a monotypic section closely related to $C$. dudleyana and the other species of section Peripetasma (Lewis \& Raven 1992). Its relationships were first revealed by evidence from restriction enzyme analysis of chloroplast DNA (Sytsma \& Gottlieb 1986a, b) and subsequent analysis of nuclear rDNA (Sytsma \& Smith 1988). Embryologically, however, C. heterandra differs from all other species of Clarkia in the histology of its nucellus. All other species of Clarkia and of the entire tribe Onagreae (except for Gayophytum), as well as Hauya, have markedly thick parietal tissue, so that the underlying tetrad of megaspores is deeply buried and positioned nearly at or a little above the bottom of the nucellus. In contrast, in C. heterandra the parietal tissue is thin at the megaspore tetrad stage, and the tetrad of megaspores is positioned at the middle of the nucellus. Later both the parietal cells above and the nucellar cells below the megaspores divide rapidly to form a massive nucellus. This marked difference in nucellar histology clearly distinguishes $C$. heterandra from other species of Clarkia and other genera of Onagreae. Since the macromolecular evidence of its close relationships with and probably derivation from Clarkia section Peripetasma is unequivocal, however, we conclude that the unusual embryological features of C. heterandra, like its distinctive morphological and anatomical characteristics, were derived within its evolutionary line after its separation from other species of Clarkia. 
Genus

\section{anther wall \\ basically 5-6 \\ cell-layered (-) \\ Type of anther Anther epidermis \\ wall development persistent $(-)$ \\ Basic $(-)$ or \\ or collapsed (t) otherwise (+)}

or otherwise $(+)$

(t)

Fuchsia

Circaea

Lopezia

Hauya

Gongylocarpus

Gayophytum

Xylonagra

Camissonia

Calylophus

Gaura

Oenothera

Stenosiphon

Clarkia

C. heterandra

Epilobium
Endothecium Tapetum glandular Tapetal cell fibrous $(-)$ or $(-)$ or amoeboid

$(-)$ or am

(+)

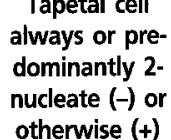

Delimitation of

microspores

Predominant

shape of micro-

spore tetrad

rahedral $(-)$

(+)

or otherwise (+)
Pollen grain

when shed 2

celled (-)

or 3-celled

(t) \& Rao (1959), Pagni (1958), Rudloff \& Schmidt (1932); for Clarkia: Håkansson (1925); for Epilobium: Håkansson (1924). See also Brewbaker (1967) for the number of cells in mature pollen in Oenothera, Clarkia and Epilobium. 
Table 3. Embryological characteristics and variation of ovules and gametophytes in Onagraceae.

\begin{tabular}{|c|c|c|c|c|c|c|c|c|c|}
\hline Genus & $\begin{array}{l}\text { Ovule anatropous } \\
(-) \text { or otherwise } \\
\qquad(+)\end{array}$ & $\begin{array}{c}\text { Inner integument } \\
\text { not retarded }(-) \\
\text { or retarded }(+) \\
\text { in early } \\
\text { development }\end{array}$ & $\begin{array}{c}\text { Micropyle formed } \\
\text { by both inner \& } \\
\text { outer integument } \\
(-) \text { or otherwise } \\
(+)\end{array}$ & $\begin{array}{l}\text { Archesporium } \\
\text { multi-celled } \\
(-) \text { or one- } \\
\text { celled }(+)\end{array}$ & $\begin{array}{c}\text { Ovule crassi- } \\
\text { nucellate }(-) \\
\text { or tenuinucellate } \\
(+)\end{array}$ & $\begin{array}{l}\text { Parietal tissue } \\
\text { thin }(5-8 \text { cells } \\
\text { thick) }(-) \text { or } \\
\text { thick }(10-20 \text { cells } \\
\text { thick) (+) }\end{array}$ & $\begin{array}{c}\text { Type of embryo } \\
\text { sac formation } \\
\text { Oenothera type } \\
(+) \text { or otherwise } \\
(-)\end{array}$ & $\begin{array}{c}\text { Starch grains } \\
\text { in nucellus } \\
\text { scanty (-) } \\
\text { or abundant } \\
(+)\end{array}$ & $\begin{array}{c}\text { Hypostase } \\
\text { absent (-) } \\
\text { or present } \\
(+)\end{array}$ \\
\hline Fuchsia & - & - & - & $-*$ & $-^{*}$ & - & $t^{*}$ & + & + \\
\hline Circaea & $-{ }^{*}$ & - & - & - & $-^{*}$ & - & $t^{*}$ & $+^{*}$ & + \\
\hline Lopezia & $-{ }^{*}$ & - & - & $-{ }^{*}$ & $-^{\star}$ & - & $+^{\star}$ & + & + \\
\hline Hauya & - & - & - & - & - & + & + & + & + \\
\hline Gongylocarpus & - & - & - & $\overrightarrow{-}$ & - & + & + & + & + \\
\hline Gayophytum & - & + & - & - & - & - & $+^{*}$ & $+^{*}$ & $t^{*}$ \\
\hline Xylonagra & - & - & - & - & - & + & + & + & + \\
\hline Camissonia & - & - & - & $-*$ & - & + & $+^{*}$ & + & $t^{*}$ \\
\hline Calylophus & - & - & - & - & - & + & + & + & + \\
\hline Gaura & $-^{*}$ & - & - & - & - & + & $t^{*}$ & + & + \\
\hline Oenothera & $-^{*}$ & - & $-*$ & $-*$ & $-*$ & + & $t^{*}$ & $+^{*}$ & $t^{*}$ \\
\hline Stenosiphon & - & - & - & - & - & + & $+^{*}$ & + & + \\
\hline Clarkia & $-{ }^{*}$ & - & $-^{*}$ & $-{ }^{\star}$ & $-^{*}$ & $+^{*}$ & $+^{*}$ & + & $t^{\star}$ \\
\hline C. heterandra & - & - & - & - & - & + & + & + & + \\
\hline Epilobium & -* & + & $-*$ & $-*$ & -* $^{*}$ & $-^{*}$ & $t^{*}$ & + & $t^{*}$ \\
\hline
\end{tabular}

* Character reported in earlier literature and confirmed in this study. References for particular genera listed as follows; for Fuchsia: Ishikawa (1918), Rodkiewicz (1973), Täckholm (1915), Werner (1915); for Circaea: Ishikawa (1918), Johansen (1934), Modilewski (1909); for Lopezia: Täckholm (1914); for Gayophytum: Johansen (1933); for Camissonia, Johansen (1931a); for Gaura: Hofmeister (1858), Ishikawa (1918); for Oenothera: Geerts (1908, 1909), Haberlandt (1927), Halac (1980), Halac \& Harte (1977), Hofmeister (1858), Hulbary \& Rao (1959), Ishikawa (1918), Johansen (1929, 1931b), Jalouzot (1978), Langendorf (1930), Modilewski (1909), O'Neal (1923), Pagni (1958), Renner (1921), Rudloff \& Schmidt (1932), Subramanyam \& Govindu (1948), Rodkiewicz, Bednara \& Pora (1971), Sniezko \& Harte (1984a, b), Werner (1915); for Stenosiphon: Johansen (1930b); for Clarkia: Håkansson (1925), Hofmeister (1858), Täckholm (1915), Werner (1915); for Epilobium: Bednara (1977), Gachechiladze (1974, 1975), Gachechiladze \& Gvaladze (1970), Modilewski (1909), Rodkiewicz (1973), Rodkiewicz \& Bednara (1974), Täckholm (1915), Werner (1915). 
Table 4. Embryological characteristics of the endosperm, embryo and seed in Onagraceae.

\begin{tabular}{|c|c|c|c|c|}
\hline Genus & $\begin{array}{l}\text { Path of pollen } \\
\text { tube porogamous } \\
(-) \text { or other- } \\
\text { wise }(+)\end{array}$ & $\begin{array}{c}\text { Type of endo- } \\
\text { sperm formation } \\
\text { Nuclear }(-) \\
\text { otherwise }(+)\end{array}$ & $\begin{array}{l}\text { Endosperm in } \\
\text { mature seed } \\
\text { present }(-) \\
\text { or absent }(+)\end{array}$ & $\begin{array}{l}\text { Type of eml } \\
\text { genesis Ona } \\
(-) \text { or othen } \\
(+)\end{array}$ \\
\hline Fuchsia & - & - & + & $?$ \\
\hline Circaea & $-^{*}$ & $-^{\star}$ & + & $-\left({ }^{\star}\right)$ \\
\hline Lopezia & - & $-*$ & + & $?$ \\
\hline Hauya & - & - & + & $?$ \\
\hline Gongylocarpus & - & - & + & $?$ \\
\hline Gayophytum & - & $-*$ & + & - \\
\hline Xylonagra & - & - & + & $?$ \\
\hline Camissonia & $-^{\star}$ & $-{ }^{\star}$ & + & - \\
\hline Calylophus & - & - & + & $?$ \\
\hline Gaura & - & - & + & $?$ \\
\hline Oenothera & $-{ }^{*}$ & $-*$ & $+^{*}$ & $-\left({ }^{*}\right)$ \\
\hline Stenosiphon & $-^{*}$ & $-*$ & + & $?$ \\
\hline Clarkia & $-{ }^{*}$ & - & + & $?$ \\
\hline C. heterandra & - & - & + & - \\
\hline Epilobium & $-*$ & $-*$ & + & $-\left({ }^{*}\right)$ \\
\hline
\end{tabular}

* Character reported in earlier literature and confirmed in this study. $\left(^{*}\right)$ Character known only in literature. References for particular genera listed as follows; for Lopezia: Hofmeister (1858); for Circaea: Johansen (1934), Souèges (1946). Werner (1915); for Gongylocarpus: Carlquist \& Raven (1966): for Gayophytum: Johansen (1933): for Camissonia, Johansen (1931a): for Oenothera: Haberlandt (1927), Hofmeister (1847), Hulbary \& Rao (1959), Langendorf (1930), Modilewski (1909), Renner (1914), Souèges (1920), Tobe, Wagner \& Chin (1987), Werner (1915); for Stenosiphon: Johansen (1930b); for Clarkia: Hofmeister (1847), Johansen (1930a); for Epilobium: Lebègue (1948a, b), Michaelis (1925), Modilewski (1909), Täckholm (1915). 
Table 5. A comparison in selected embryological characters among genera of Onagraceae.

Genus

Type of
anther wall
development

Ovule

archesporium

development

Tribe Jussiaeeae

Ludwigia ${ }^{3}$

Tribe Fuchsieae

Fuchsia

Tribe Circaeeae

Circaea

Tribe Lopezieae

Lopezia

Tribe Hauyeae

Hauya

Tribe Onagreae

Gongylocarf

Gayophytum

Xylonagra

Camissonia

Calylophus

Gaura

Oenothera

Stenosiphon

Clarkia

Tribe Epilobieae

Epilobium

$\begin{array}{cc}\text { Basic } & \text { 1-celled } \\ \text { Basic } & \text { Multi-celled } \\ \text { Basic } & \text { Multi-celled } \\ & \\ \text { Basic } & \text { Multi-celled } \\ & \\ \text { Monocot. } & \text { Multi-celled } \\ & \\ \text { Basic } & \\ \text { Basic } & \text { Multi-celled } \\ \text { Basic } & \text { Multi-celled } \\ \text { Basic } & \text { Multi-celled } \\ \text { Monocot. } & \text { Multi-celled } \\ \text { Monocot. } & \text { Multi-celled } \\ \text { Basic } & \text { Multi-celled } \\ \text { Basic } & \text { Multi-celled } \\ \text { Monocot. } & \text { Multi-celled } \\ & \text { Multi-celled }\end{array}$

Not retarded

Not retarded

Not retarded

Not retarded

Not retarded

Not retarded

Retarded

Not retarded

Not retarded

Not retarded

Not retarded

Not retarded

Not retarded

Not retarded

Multi-celled

Retarded
Parietal

tissue

in ovule

Thin

Thin

Thin

Thin

Thick

Thick

Thin

Thick

Thick

Thick

Thick

Thick

Thick

Thick

\section{Type of septa}

dividing

microsporogenous

tissue ${ }^{1}$

Tapetal/parenchym.

Tapetal

Tapetal

Tapetal

Parenchym.

Tapetal

Tapetal

Tapetal

Tapetal

Parenchym

Parenchym.

Tapetal

Tapetal

Parenchym.
Histology of

outer integument ${ }^{2}$

Tapetal

Dermal

Subdermal

Subdermal

Subdermal

Partially subdermal I

Dermal

Dermal

Dermal

Dermal

Partially subdermal I

Partially subdermal I

Partially subdermal II

Partially subdermal II

Dermal

Thin

Dermal

${ }^{1}$ Data from Tobe \& Raven (1986a). Tapetal = tapetal septa; Parenchym. = parenchymatous septa.

2 Data from Tobe \& Raven (1985). Dermal = the outer integument (oi) is formed only by derivatives of dermal initials of an ovule primordium, no derivatives of subdermal initials contributing to the formation of oi; Partially subdermal I and $\mathrm{II}=$ derivatives of subdermal initials participate in the formation of the oi but are restricted to the basal part of oi $(\mid)$ or reach more than half as much as (but less than) the whole length of oi $(I)$; Subdermal = derivatives of subdermal initials participate well in the formation of the oi and reach up to its tip.

${ }^{3}$ Data from Tobe \& Raven (1986b) 


\section{Acknowledgements}

This study was supported by U.S. National Science Foundation grants to PR, most recently as BSR-8906848. We are grateful to Peter C. Hoch for his comments on the manuscript, and to many people who have collected plant materials for this study, as noted in Table 1.

\section{References}

Baum, D.A., Sytsma, K.J. \& Hoch, P.C. (1994) A phylogenetic analysis of Epilobium (Onagraceae) based on nuclear ribosomal DNA sequences. Syst. Bot. 19: 363-388.

Bednara, J. (1977) Female gametophyte and pollen tube of Epilobium palustre L. Acta Soc. Bot. Poloniae 46: 603-616.

Beer, R. (1905) On the development of the pollen grain and anther of some Onagraceae. Beih. Bot. Centralbl. 19: 286-313.

Brewbaker, J.L. (1967) The distribution and phylogenetic significance of binucleate and trinucleate pollen grains in the angiosperms. Amer. J. Bot. 54: 1069-1083.

Bult, C.J. \& Zimmer, E.A. (1993) Nuclear ribosomal RNA sequences for inferring tribal relationships within Onagraceae. Syst. Bot. 18: 48-63.

Carlquist, S. \& Raven, P.H. (1966) The systematics and anatomy of Gongylocarpus (Onagraceae). Amer. J. Bot. 53: 378-390.

Chase, M.W. et al. (42 authors) (1993) Phylogenetics of seed plants: an analysis of nucleotide sequences from the plastid gene $r b c \mathrm{~L}$. Ann. Missouri Bot. Gard. 80: 528-580.

Conti, E., Fischbach, A. \& Sytsma, K.J. (1993) Tribal relationships in Onagraceae: implications from rbcL sequence data. Ann. Missouri Bot. Gard. 80: 672-685.

Crisci, J.V., Zimmer, E.A., Hoch, P.C., Johnson, G.B., Mudd, C. \& Pan, N. (1990) Phylogenetic implications of ribosomal DNA restriction site variation in the plant family Onagraceae. Ann. Missouri Bot. Gard. 77: 523-538.

Dahlgren, R. \& Thorne, R.F. (1984) The order Myrtales: circumscription, variation and relationships. Ann. Missouri Bot. Gard. 71: 633-699.

Davis, B.M. (1909) Cytological studies on Oenothera. 1. Pollen development of Oenothera grandiflora. Ann. Bot. (London) 23: 551-571.

Davis, G.L. (1966) Systematic Embryology of the Angiosperms. (John Wiley \& Sons: New York).

Eyde, R.H. (1981) Reproductive structures and evolution in Ludwigia (Onagraceae). III. Vasculature, nectaries, conclusions. Ann. Missouri Bot. Gard. 68: 470-503.

Gachechiladze, M.I. (1974) Development of the Oenothera-type embryo sac. Soobs. Akad. Nauk Gruzinsk. SSR 76: 433-436. (In Russian with English summary).

Gachechiladze, M.I. (1975) Deviations in the embryo sac of the type Oenothera. Soobs. Akad. Nauk Gruzinsk. SSR 79: 437-440. (In Russian with English summary).

Gachechiladze, M.I. \& Gvaladze, G.E. (1970) On the embryological study of Onagraceae. Soobs. Akad. Nauk Gruzinsk. SSR 60: 677-680. (In Russian with English summary).

Gates, R.R. (1911) Pollen formation in Oenothera. Ann. Bot. (London) 25: 909-940.

Geerts, J.M. (1908) Beiträge zur Kenntnis der cytologischen Entwicklung von Oenothera lamarckiana. Ber. Deutsch. Bot. Ges. 26: 608-614.

Geerts, J.M. (1909) Beiträge zur Kenntnis der Cytologie und der partiellen Sterilität von Oenothera lamarckiana. Recueil Trav. Bot. Néerl. 5: 93-206.

Haberlandt, G. (1927) Zur Zytologie und Physiologie des wieblichen Gametophyten von Oenothera. Sitzungsber. Preuss. Akad. Wiss. 1927: 33-47.

Håkansson, A. (1924) Beiträge zur Zytologie eines Epilobium-Bastardes. Bot. Not. 1924: 269-278.

Håkansson, A. (1925) Zur Zytologie der Gattung Godetia. Hereditas 6: 257-274.

Halac, N. de (1980) Callose deposition during megagametogenesis in two species of Oenothera. Ann. Bot. (London) 46: 473-477.

Halac, N. de \& Harte, C. (1977) Different patterns of callose wall formation during megasporogenesis in two species of Oenothera (Onagraceae). Pl. Syst. Evol. 127: 23-38.

Hoch, P.C., Crisci, J.V., Tobe, H. \& Berry, P.E. (1993) A cladistic analysis of the plant family Onagraceae. Syst. Bot. 18: 31-47.

Hoch, P.C. \& Raven, P.H. (1992) Boisduvalia, a coma-less Epilobium (Onagraceae). Phytologia 73: 456-459. 
Hofmeister, W. (1847) Untersuchungen des Vorgangs bei der Befruchtung der Oenothereen. Bot. Zeitung (Berlin) 5: 785-792.

Hofmeister, W. (1858) Neuere Beobachtungun über Embryobildung der Phanerogamen. Jahrb. Wiss. Bot. 1: 82-188.

Hubert, M.E. de (1896) Recherches sur le sac embryonnaire des plantes grasses. Ann. Sci. Nat. Bot. 2: $37-128$.

Hulbary, R.L. \& Rao, A.N. (1959) Flower development and gametogenesis in Oenothera laciniata Hill. Proc. Iowa Acad. Sci. 66: 91-97.

Ishikawa, M. (1918) Studies on the embryo sac and fertilization in Oenothera. Ann. Bot. (London) 32: 279-317.

Jalouzot, M.F. (1978) Différenciation des éléments de la tétrade femelle chez Oenothera erythrosepala. Bull. Soc. Bot. France 125: 167-170.

Johansen, D.A. (1928) The hypostase and seed sterility in the Onagraceae. Madroño 1: 165-167.

Johansen, D.A. (1929) Studies on the morphology of Onagraceae. I. The megagametophyte of Hartmannia tetraptera. Bull. Torrey Bot. Club. 56: 285-298.

Johansen, D.A. (1930a) Studies on the morphology of the Onagraceae. II. Embryonal manifestation of fasciation in Clarkia elegans. Bot. Gaz. (Crawfordsoille) 90: 75-91.

Johansen, D.A. (1930b) Studies on the morphology of the Onagraceae. IV. Stenosiphon linifolium. Bull. Torrey Bot. Club 57: 315-326.

Johansen, D.A. (1931a) Studies on the morphology of the Onagraceae. III. Taraxia ovata (Nutt.) Small. Ann. Bot. (London) 45: 111-124.

Johansen, D.A. (1931b) Studies on the morphology of the Onagraceae. VI. Anogra pallida. Amer. J. Bot. 18: 854-864.

Johansen, D.A. (1933) Studies on the morphology of the Onagraceae. VII. Gayoplytum ramosissimum. Bull. Torrey Bot. Club 60: 1-8.

Johansen, D.A. (1934) Studies on the morphology of the Onagraceae. VIII. Circaea pacifica. Amer. J. Bot. 21: 508-510.

Johnson, L.A.S. \& Briggs, B.G. (1984) Myrtales and Myrtaceae - A phylogenetic analysis. Ann. Missouri Bot. Gard. 71: 700-756.

Joshi, A.C. \& Venkateswarlu, J. (1935a) Embryological studies in the Lythraceae. 1. Lawsonia inermis. Proc. Indian Acad. Sci. 2: 481-493.

Joshi, A.C. \& Venkateswarlu, J. (1935b) Embryological studies in the Lythraceae. 2. Lagerstroemia. Proc. Indian Acad. Sci. 2: 523-534.

Joshi, A.C. \& Venkateswarlu, J. (1936) Embryological studies in the Lythraceae III. Proc. Indian Acad. Sci. 3: 377-400.

Langendorf, J. (1930) Zur Kenntnis der Genetik und Entwicklungsgeschichte von Oenothera fallax, rubirigida und Hooker-albata. Bot. Arch. 29: 474-530.

Lebègue, A. (1948a) Embryogénie des Oenotheracées, Développement de l'embryon chez l'Epilobium montanum L. Bull. Soc. Bot. France 95: 173-178.

Lebègue, A. (1948b) Embryogénie des Oenotheracées. Développement de l'embryon chez l'Epilobium spicatum Lam. Compt. Rend. Hebd. Séances Acad. 226: 429-430.

Lewis, H \& Raven, P.H. (1992) New combinations in the genus Clarkia (Onagraceae). Madrono 39: 163-169.

Maheshwari, P. (1950) An Introduction to the Embryology of Angiosperms. (McGraw-Hill: New York).

Michaelis, P. (1925) Zur Cytologie und Embryoentwicklung von Epilobium. Ber. Deutsch. Bot. Ges. 43: $61-67$.

Modilewski, J. (1909) Zur Embryobildung einiger Onagraceen. Ber. Deutsch. Bot. Ges. 27: 287-292.

Nagendran, C.R. \& Dinesh, M.S. (1989) The Embryology of Angiosperms: A Classified Bibliography (1965-1985). (Indira Publishing House: Oak Park).

O'Neal, C.E. (1923) A study of the embryo sac development and accompanying phenomena in Oenothera rubrinervis. Bull. Torrey Bot. Club 50: 133-146.

Pagni, P. (1958) Richerche cito-embriologiche su Oenothera acaulis Cav. Caryologia 11: 181-202.

Raven, P.H. (1979) A survey of reproductive biology in Onagraceae. New Zealand J. Bot. 17: 575-593.

Raven, P.H. (1988) Onagraceae as a model of plant evolution. Pp 85-107 in L.D. Gottlieb \& S.K. Jain, (eds), Plant Evolutionary Biology. (Chapman and Hall: London).

Renner, O. (1914) Befruchtung und Embryobildung ei Oenothera Lamarckiana und einiger verwandten Arten. Flora 107: 115-150.

Renner, O. (1921) Heterogamie im weiblichen Geschlecht und Embryosackentwicklung bein den Önotheren. Z. Bot. 13: 609-621. 
Rodkiewicz, B. (1973) Callose walls in megaspores in Fuchsia and Epilobium. Caryologia 25 (Suppl.): $59-66$.

Rodkiewicz, B. \& Bednara, J. (1974) Distribution of organelles and starch grains during megasporogenesis in Epilobium. Pp. 89-95 in H.L. Linskens, (ed), Fertilization in Higher Plants. (North-Holland Publishing Company: Amsterdam).

Rodkiewicz, B., Bednara, J. \& Pora, H. (1971) Alternative localization of the active megaspore in tetrads in Oenothera muricata. Bull. Acad. Polon. Sci., Sér. Sci. Biol. 19: 691-694.

Rodkiewicz, B. \& Sniezko, R. (1978) Differentiation of functional megaspore in Onagraceae. Bull. Soc. Bot. France 125: 163-166.

Rudloff, C.F. \& Schmidt, M. (1932) Untersuchungen über den Einfluss ungünstiger Witterunfsverhältnisse auf die Embryosackentwicklung bei verschiedenen Oenotheren. Planta 18: 104-167.

Seshavataram, V. (1970) Onagraceae. In B.R. Seshachar, (ed), Proceedings of the Symposium on Comparative Embryology of Angiosperms. Bull. Indian Natl. Sci. Acad. 41: 220-225.

Sniezko, R. \& Harte, C. (1984a) Polarity and competition between megaspores in the ovule of Oenothera hybrids. Pl. Syst. Evol. 144: 83-97.

Sniezko, R. \& Harte, C. (1984b) Callose pattern and polarization phenomena in the ovules in the F2-hybrids between Oenothera hookeri and O. suaveolens. Pl. Syst. Evol. 147: 79-90.

Souèges, R. (1920) Embryogénie des Oenothéracées. Développement de l'embryon chez l'Oenothera biennis L. Compt. Rend. Hebd. Séances Acad. Sci. 170: 946-948.

Souèges, R. (1946) Embryogénie des Oenothéracées. Développment de l'embryon chez de Circaea lutetiana L. Compt. Rend. Hebd. Séances Acad. Sci. 223: 700-702.

Subramanyam, K. \& Govindu, H.C. (1948) The development of the female gametophyte in Oenothera odorata Jacq. J. Indian Bot. Soc. 27: 25-30.

Sytsma, K.J. \& Gottlieb, L.D. (1986a) Chloroplast DNA evidence for the origin of the genus Heterogaura from a species of Clarkia (Onagraceae). Proc. Natl. Acad. U.S.A. 86: 5554-5557.

Sytsma, K.J. \& Gottlieb, L.D. (1986b) Chloroplast DNA evolution and phylogenetic relationships in Clarkia sect. Peripetasma (Onagraceae). Evolution 40: 1248-1261.

Sytsma, K.J. \& Smith, J.F. (1988) DNA and morphology: comparisons in the Onagraceae. Ann. Missouri Bot. Gard. 75: 1217-1237.

Sytsma, K.J., Smith, J.F. \& Hoch, P.C. (1991) A chloroplast DNA analysis of tribal and generic relationships within Onagraceae. Amer. J. Bot. 78: 222 (abstract).

Täckholm, G. (1914) Zur Kenntnis der Embryosackentwicklung von Lopezia coronata Andr. Svensk Bot. Tidskr. 8: 223-234.

Täckholm, G. (1915) Beobachtungen über die Samenentwicklung einiger Onagraceen. Svensk Bot. Tidskr. 9: 294-361.

Tobe, H. \& Raven, P.H. (1983) An embryological analysis of Myrtales: its definition and characteristics. Ann. Missouri Bot. Gard. 70: 71-94.

Tobe, H. \& Raven, P.H. (1984) The number of cells in the pollen of Melastomataceae. Bot. Mag. (Tokyo) 97: 131-136.

Tobe, H. \& Raven, P.H. (1985) The histogenesis and evolution of integuments in Onagraceae. Ann. Missouri Bot. Gard. 72: 451-468.

Tobe, H. \& Raven, P.H. (1986a) Evolution of polysporangiate anthers in Onagraceae. Amer. J. Bot. 73: 475-488.

Tobe, H. \& Raven, P.H. (1986b) A comparative study of the embryology of Ludwigia (Onagraceae): characteristics, variation, and relationships. Ann. Missouri Bot. Gard. 73: 768-787.

Tobe, H., Raven, P.H. \& Peng, C.-I. (1988) Seed coat anatomy and relationships of Ludwigia sects. Microcarpium, Dantia, and Miquelia (Onagraceae), and notes on fossil seeds of Ludwigia from Europe. Bot. Gaz. (Crawfordsville) 149: 450-457.

Tobe, H., Wagner, W.L. \& Chin, H.-C. (1987) A systematic and evolutionary study of Oenothera: seed coat anatomy. Bot. Gaz. (Crawfordsville) 148: 235-257.

Venkateswarlu, J. (1937) Structure and development of the embryo sac of Pemphis acidula. J. Indian Bot. Soc. 16: 259-262.

Werner, E. (1915) Zur Ökologie atypischer Samenanlagen. Beih. Bot. Centralbl. 33: 1-11. 